\title{
Liberalizam i religija
}

Stephen Nikola Bartulica*

UDK: $330.82: 2$

stjepo.bartulica@unicath.hr

2:330.82

Izvorni znanstveni rad / Original scientific paper Primljeno: 20. siječnja 2016. Prihvaćeno: 29. veljače 2016.

Autor istražuje odnos između političke filozofije liberalizma i religije u sekularnoj državi. Još prije protestantske reformacije Machiavelli je iznio svoju teoriju sekularne države koja je slobodna od svakog vanjskog utjecaja, pa tako i od Crkve. Hobbes se zalaže za državu koja će biti jedini zakonodavac i imati konačnu riječ $i$ u vjerskim pitanjima. Kasnije se liberalizam pokušava prilagoditi tako da osigura vjerske slobode, što je jedno vrijeme i uspijevao, primjerice u SAD-u. Nedavni događaji, međutim, upozoravaju na zabrinjavajući smjer kretanja koji ukazuje na stvaranje novih sekularnih »dogmi« koje nisu u skladu s kršćanskim naukom.

Ključne riječi: liberalizam, religija, država, Machiavelli, Hobbes, Locke, sloboda, totalitarizam.

\footnotetext{
* Dr. sc. Stephen Nikola Bartulica, viši asistent na Hrvatskom katoličkom sveučilištu, Ilica 242, HR-10000 Zagreb.
} 


\section{Uvod}

Slučaj s Amerikankom Kim Davis, službenicom Okružnoga suda u saveznoj državi Kentucky, dobro pokazuje da vjerska uvjerenja mogu lako doći u sukob sa zahtjevima službenih javnih institucija. ${ }^{1}$ Još ranije, neposredno nakon presude Vrhovnog suda u slučaju Obergefell, neki su tražili da se Katoličkoj crkvi i drugim vjerskim zajednicama ukine status koji im jamči da ih vlada ne može oporezivati (tax-exempt), jer njihova doktrina o braku više nije u skladu s novim sekularnim dogmama. Što se dogodilo u SAD-u da su danas temeljne slobode i prava postale sporne, a prema nekima i ugrožene? Povijest vjerske slobode u SAD-u jest složena, ali je jedno od početka bilo jasno: svrha prvog članka odredaba o temeljnim pravima (Bill of Rights) američkoga Ustava je bila - inter alia - zaštititi vjerske ustanove od političkog pritiska i zajamčiti njima i njihovim članovima pravo da nesmetano obavljaju svoje obveze prema Bogu i prakticiraju svoju vjeru. Mogućnost da država ograniči ta prava ili prisili vjernike da prešućuju svoja uvjerenja jest nešto što se dugo činilo nemogućim, ali s vremenom postaje sve realnije. Članak će pokušati obrazložiti glavna pitanja u razvoju liberalne sekularne države s naglaskom na njezino shvaćanje uloge religije. Iznosit će tezu da su filozofske pretpostavke, koje su bile prisutne u političkoj filozofiji Machiavellija i Hobbesa, već sadržavale ozbiljnu prijetnju vjerskoj slobodi.

Osnivači SAD-a, ${ }^{2}$ prije svega, Benjamin Franklin, John Adams, Thomas Jefferson, James Madison, nisu htjeli ponoviti traumatično iskustvo europskih država koje su često davale povlašteni položaj jednoj crkvi na štetu svih ostalih, što je dovelo do progona onih koji nisu pripadali službenoj crkvi. Glavna je politička zadaća bila stvoriti nov temelj jedinstva da bi se ujedinilo više saveznih država (izvorno njih 13) pod jednom vladom, a istovremeno sačuvati tim državama određenu samostalnost. ${ }^{3}$ Što se tiče religije, vodeći ljudi SAD-a htjeli su osigurati slobodu prakticiranja (free exercise), a svrha ustava je bila da se što jasnije definiraju ovlasti savezne vlade da bi njezina moć bila ograničena. Ovdje nije namjera obraditi glavne tekstove u osnivanju SAD-a, nego istaknuti da su osnivači SAD-a bili vođeni filozofijom koja je uključivala uvjerenja da država nije zadnja razina te da ona mora poštivati određene granice. Znači, osnivači

\footnotetext{
${ }^{1}$ Službenica Davis odbila je potpisati potvrdu o braku jednom istospolnom paru. Završila je $\mathrm{u}$ zatvoru zbog neposlušnosti odredbama suda (Contempt of court), a puštena je na slobodu poslije nekoliko dana. Ovo je prvi takav slučaj otkad je Vrhovni sud SAD-a donio presudu u slučaju Obergefell protiv Hodgesa kojom je redefinirao brak.

${ }^{2}$ Ovdje se prije svega misli na pojedince koji su imali vodeću ulogu u borbi protiv britanske vlasti koja je trajala od 1775 . do 1783 . godine pa sve do usvajanja ustava 1787 . godine.

${ }^{3}$ Na početku dokumenta Federalist Papers autori (James Madison, Alexander Hamilton i John Jay) ističu šest glavnih namjera, a prva jest pokazati korisnost unije za politički razvoj zemlje. Amerikanci su bili vrlo suzdržani prema svakoj središnjoj vlasti, s obzirom na loše iskustvo pod britanskom krunom, tako da su tvorci novog ustava morali uvjeriti svoje sugrađane u opravdanost prenošenja nekih ovlasti na novu vladu.
} 
nisu bili zagovornici Machiavellijeve i Hobbesove vizije države. Međutim, pokušat ćemo pokazati da nedavni događaji, pogotovo pokušaj da se redefinira brak, ukazuju na to da se liberalni model, koji je na snazi u SAD-u, zapravo počeo urušavati te da država postupno nameće svoju »sekularnu religiju u u kojoj će pravovjerni katolici i drugi kršćani imati sve manje slobode u prakticiranju svoje vjere.

\section{Machiavelli i smisao politike}

Što se podrazumijeva pod nazivom liberalizam? Je li ova politička doktrina jedini jamac za osiguravanje osnovnih prava i slobode? Kakav je odnos prema religiji? Je li nužno antagonistički ili može li liberalizam, da bi opstao, zapravo ovisiti o religiji? Prema francuskom filozofu Pierreu Manentu, riječ je o intelektualnom pokretu koji je nastao prije 500 godina s glavnim ciljem da oslobodi društvo od utjecaja Katoličke crkve te da država preuzme njezinu ulogu. ${ }^{4}$ Dakle, u ovom tumačenju je sloboda od kršćanstva glavni cilj ove doktrine. Međutim, postoji i druga teorija o nastanku liberalizma koja ističe da je zapravo riječ o reakciji iz nužnosti nakon raspada europskog poretka koji je bio utemeljen na vjerskoj osnovi. ${ }^{5}$ Iz ovog kuta gledanja kršćani su velikim dijelom sami krivi za situaciju koja je omogućila da liberalizam postane vodeće filozofsko mišljenje, jer je iskustvo vjerskih ratova tijekom 17. stoljeća uvjerilo Europljane da religija više ne može biti glavno načelo za uređenje društva.

Upravo je to europsko iskustvo snažno određivalo visok senzibilitet za vjersku slobodu koju su osnivači SAD-a imali i njegovali. Treba ovdje naglasiti da riječ »država« nije postojala prije 16. stoljeća, barem ne u smislu kako se danas koristi. Engleski povjesničar političke teorije Quentin Skinner upozorava da »nijedan pisac prije sredine 16. stoljeća nije koristio izraz 'država' u onom smislu kako ga razumijemo u moderno doba«. ${ }^{6}$ Kako zapravo moderno doba shvaća državu? Danas nam riječ »država« označuje apstraktnu tvorevinu koja postoji bez obzira na konkretne ljude koji žive u njoj, te utjelovljuje niz institucija koje provode zakone unutar njenih granica. Ovakvo shvaćanje prvo nastaje kod talijanskog pisca i diplomata Niccole Machiavellija koji je htio onemogućiti Crkvi da kontrolira vladara te na taj način osigurati potpunu autonomiju političke sfere. ${ }^{7}$ Katolička crkva je uvijek razlikovala religijsku i političku sferu, ali

\footnotetext{
${ }^{4}$ Usp. Pierre MANENT, The Intellectual History of Liberalism, Princeton, 1995, viii.

${ }^{5}$ Ovo tumačenje ističe, primjerice, engleski povjesničar Christopher Dawson koji je tvrdio da je protestantska reformacija glavni uzrok nastanka liberalizma u Europi. Ističe da, čim je religija prestala biti izvor jedinstva, ljudi su bili prisiljeni pronaći novu osnovu za uređenje društva (usp. Christopher DAWSON, The Dividing of Christendom, New York, 1965, 3-4).

${ }^{6}$ Quentin SKINNER, The Foundations of Modern Political Thought, Cambridge, 1978, xxiii.

7 Usp. Benjamin WIKER, Worshipping the State. How Liberalism Became our State Religion, Washington DC, 2013, 106.
} 
je Machiavelli prvi podigao »zid« između Crkve i države. Za Machiavellija nije dovoljno osloboditi vladara od bilo kojeg utjecaja Crkve, nego ga je potrebno okrenuti protiv kršćanskoga morala kako bi zadržao svoju vlast. ${ }^{8}$ To se jasno vidi u sljedećem odlomku:

»Vladar, a navlastito nov vladar, ne može se držati svega onoga zbog čega ljude smatraju za dobre, jer je, da bi održao vlast, vrlo često primoran raditi protiv onoga što nam zapovijeda vjernost, milosrđe, čovječnost i vjera. Stoga on mora imati duh sposoban da se okrene već prema tome kako mu to nalaže vjetar varljive sreće i neprestana promjenljivost okolnosti; ne smije se, kako već gore rekoh, ako može udaljavati od dobra; ali mora znati i zagaziti u zlo, bude li prisiljen. ${ }^{9}$

Dakle, nije dovoljno da vladar bude usredotočen isključivo na zemaljski svijet, nego savjetuje da mora odbaciti sve moralne skrupule pa i »zagaziti u zlo« kako bi zadržao vlast. Time Machiavelli opravdava sva sredstva u postizanju političkih ciljeva, što označuje bit doktrine - makijavelizam. Za Machiavellijeva vladara ne postoji više napetost između zemaljskog i Božjeg kraljevstva jer Božjeg kraljevstva zapravo i nema. Politička vlast se treba usredotočiti samo na zemaljske probleme, te se ne smije opterećivati pitanjima vječnog života, $t j$. spasenja duše. Ova je doktrina početak stvaranja potpuno sekularne države koja će imati apsolutnu autonomiju i neće biti podređena bilo kojem vanjskom autoritetu. Ovo shvaćanje države pripada modernom dobu, tako da Machiavelli simbolizira veliki prijelaz u povijesti političke filozofije. ${ }^{10}$

Ono za što su se veliki filozofi drevne kulture zalagali - pravednu političku zajednicu- za Machiavellija je iluzija koja se nikad neće ostvariti. Leo Strauss objašnjava da, kad Machiavelli govori o zamišljenim kraljevstvima, ne misli samo na filozofe; misli također na Božje kraljevstvo, koje je s njegova gledišta izmišljotina vizionara. ${ }^{11}$ Upravo je ova tvrdnja, da je Božje kraljevstvo izmišljotina, ono što najviše određuje Machiavellijevu filozofiju, jer sve ostalo slijedi ovu pretpostavku. Ono što je pravo umijeće kod vladara, međutim, jest da podanicima ne otkrije ovu »istinu«, jer je ipak korisno ako i dalje drže do moralnih normi i prakticiraju svoju vjeru. Dakle, kod Machiavellija zid između Crkve i države mora biti nevidljiv i ostaje unutar vladareva uma, tako da samo on smije biti oslobođen od tereta razmišljanja o vječnom životu. ${ }^{12}$ Vanjska pobožnost služi kao maska za unutarnji amoralni makijavelizam.

${ }^{8}$ Usp. Harvey MANSFIELD, Machiavelli's Virtue, Chicago, 1996, 288-291.

9 Niccolo MACHIAVELLI, Vladar, Zagreb, 1983, 70-71.

${ }^{10}$ Američki filozof Leo Strauss kaže da je Machiavelli raskinuo sa svim prethodnim filozofima politike. Ističe da je Machiavelli bio prvi koji je eksplicitno zagovarao da politički vladar bude potpuno neovisan od svakog drugog autoriteta, prije svega, vjerskog.

${ }^{11}$ Usp. Leo STRAUSS, Joseph CROPSEY (ur.), Povijest političke filozofije, Zagreb, 2006, 209.

${ }^{12}$ Wiker navodi tri razloga zašto je Machiavelli još skrivao svoje prave namjere. Prvo, kršćanstvo još snažno oblikuje europsku kulturu 16. stoljeća. Drugo, upravo jer je kršćanstvo imalo velik utjecaj na ljude, to može vladaru služiti kao vrlo koristan alat u ostvarivanju njegovih namjera. Treće, Machiavelli se slaže s nekim drevnim grčkim i rimskim filozofima (primjerice Polibije, 
Machiavelli ne priznaje nikakvu teologiju osim građanske teologije, teologije koja služi državi i kojom se država služi ili ne služi, ovisno o okolnostima. U Vladaru se ne spominju savjest, opće dobro, tirani, to jest razlika između kralja i tiranina, ni nebo. Valja spomenuti da ne govori o razlici između zemaljskog i nebeskog, ili između ovoga i drugog vječnog života, a nikada ne spominje dušu..$^{13}$ Nacionalna sekularna država postaje nov temelj jedinstva, a moral se podređuje političkim interesima, što na kraju znači da jedino gola moć može spriječiti anarhiju. Prema njemu se politika morala odvojiti od kršćanskog moralnog nauka te dobiti pravo da stvori svoj zemaljski poredak na novim principima. Machiavelli nije nikad iznio razrađenu sveobuhvatnu političku doktrinu, jer je bio previše usredotočen na zbivanja u svom neposrednom okruženju, ali je udario temelje novom pristupu politici koji ne priznaje drugi ili viši autoritet.

\section{Hobbes i nastanak sekularne države}

Pored Machiavellija, drugi filozof koji je najviše učinio da se sekularna država uspostavi kao tvorevina s gotovo neograničenim ovlastima jest Thomas Hobbes. Zanimljivo je da se Hobbes u svojim radovima nije pozvao na Machiavellija, iako je Machiavellijevo razmišljanje o državi vrlo prisutno kod Hobbesa. ${ }^{14}$ Što se tiče konkretnih okolnosti, možda je glavna razlika bila što je Machiavelli pisao prije protestantske reformacije, u vrijeme kad je Katolička crkva još uvijek bila glavni vjerski autoritet, barem u zapadnoj Europi, dok je Hobbes pisao nakon reformacije kad je religija postala izvor sukoba, a ne jedinstva. ${ }^{15}$ Hobbes je smatrao da je njegova politička filozofija posve nova, te držao da je on pravi utemeljitelj političke filozofije. ${ }^{16}$ Budući da se Engleska nalazila u stanju građanskog rata, uvelike vjerskog rata između anglikanaca i puritanaca, Hobbes je promatrao religiju kao veliku prijetnju stabilnosti zemlje. Dakle, glavni je politički problem bio da država nije imala potpunu vlast nad religijom, što je značilo da je religija mogla ugroziti suverenitet kralja. Za Hobbesa nije toliko zabrinjavajuće što se kršćani međusobno sukobljavaju, nego što su prijetnja državnom poglavaru.

Hobbesovo rješenje temelji se na dvjema glavnim filozofskim pretpostavkama - materijalizmu i moralnom relativizmu. Materijalizam mu je nužan da bi se riješio problema ljudske duše, zato mora odbaciti klasičnu metafiziku iz svoje

Livije i Plutarh) koji su tvrdili da, iako masovne religije nisu istinite, mogu biti korisne u kontroliranju masa. Worshipping the State: How Liberalism Became our State Religion, 110-111.

${ }^{13}$ Usp. Strauss, Cropsey (ur.), Povijest političke filozofije..., 212.

${ }^{14}$ Strauss tvrdi da je revoluciju koju je Hobbes izveo snažno pripremio Machiavelli [usp. Strauss, Cropsey (ur.), Povijest političke filozofije..., 208].

${ }^{15}$ Ovo upućuje na to da sekularna država nije nastala zbog vjerskih sukoba između kršćana, nego je bila zamišljena od strane Machiavellija prije potestantske reformacije.

${ }^{16}$ Usp. Strauss, Cropsey (ur.), Povijest političke filozofije..., 208. 
političke filozofije. Što misli o metafizici može se vidjeti u sljedećem odlomku Levijatana:

»Zaista, ono što je tamo napisano (Aristotelova Metafizika), najvećim je dijelom toliko daleko od moći poimanja i toliko protivno prirodnom razumu da svatko tko i pomisli da u njoj ima ičeg što se može razumjeti pomoću nje, to nužno mora smatrati natprirodnim. Ta nam metafizika, pomiješana sa Svetim pismom u skolastičko bogoslovlje, govori da u svijetu postoje izvjesne biti odvojene od tijela. (...) Svijet je tjelesan, to jest svijet je tijelo i ima razmjere veličine, naime, dužinu, širinu i dubinu (...) svaki dio svemira je tijelo te ono što nije njegov dio nije ništa i, dosljedno tome, nije nigdje. « ${ }^{17}$

Hobbes tvrdi da sve što postoji jest materijalno, tako da ne postoji duhovna sfera nad kojom bi Crkva rabila svoju moć. Stoga se srednjovjekovni model dvaju autoriteta - duhovnog (sacerdotium) i materijalnog (regnum) - raspada, a sva je vlast predana zemaljskom vladaru. Hobbesov apsolutizam podrazumijeva materijalizam jer ne postoji ništa izvan ili iznad države. Druga filozofska pretpostavka je moralni relativizam jer Hobbes želi da država bude jedini zakonodavac, tako da mora eliminirati sve moralne norme koje proizlaze iz naravi ili Božjeg zakona. ${ }^{18}$ Hobbesov moralni relativizam logično slijedi njegov materijalizam jer materija nije ni dobra ni zla, jednostavno postoji. Budući da je čovjek samo tijelo sastavljeno od nevidljivih atoma, naša djela, misli i želje se mogu reducirati na mehaničke radnje i nužne reakcije atoma. Ono što zovemo dobrim ili zlim, dakle, samo su subjektivni tjelesni odgovori na vanjske podražaje, što Hobbes objašnjava ovako:

»Što god bilo predmet nečijeg poriva ili želje, to je ono što on sa svoje strane naziva dobro, dok predmet svoje mržnje i odbojnosti naziva zlom, a predmet svoga prezira ništavnim $i$ bezvrijednim. Naime, te riječi dobro, zlo i bezvrijedno koriste se uvijek u odnosu prema osobi koja ih koristi. Nema ničega što je naprosto i apsolutno takvo niti pak postoji ikakvo opće pravilo za dobro i loše koje bi se moglo uzeti iz prirode samih predmeta, već samo iz osobe čovjeka (tamo gdje ne postoji država).«19

Ono što je revolucionarno u Hobbesovoj filozofiji jest da potpuno relativizira moralno prosuđivanje, tako da se zakon više ne temelji u objektivnoj istini koja vrijedi za sve, nego isključivo u volji vladara, odnosno, političkoj vlasti. Ispravno i neispravno postaju umjetne kategorije, nešto što samo ovisi o ljudskoj volji. U njegovu poznatom opisu »prirodnog stanja« Hobbes kaže da svi imaju prirodno pravo činiti ono što smatraju potrebnim da bi se održali. Tvrdnja da ljudi imaju pravo činiti što god žele da bi preživjeli, podrazumijeva pretpostavku da ne postoji grijeh i da nema objektivnog moralnog standarda koji bi nas obvezivao.

\footnotetext{
${ }^{17}$ Thomas HOBBES, Levijatan, Zagreb, 2004, 436.

${ }^{18}$ Hobbes odbacuje naravni zakon i postaje prvi zagovornik pravnog pozitivizma. Zakon više nema glavno uporište u razumu nego u ljudskoj volji, odnosno volji suverena.

${ }^{19}$ Hobbes, Levijatan..., 41.
} 
Hobbesova teorija također pretpostavlja da čovjek po prirodi nije društveno ili političko biće, a ono što ga primarno pokreće nije razum nego strasti, među kojima je najsnažnija strah od nasilne smrti. ${ }^{20} \mathrm{U}$ prirodnom smo stanju svi jednaki, a to znači da smo jednako sposobni međusobno se ubijati.

Dakle, građansko društvo, po njemu, nastaje na posve umjetan način, odnosno, društvenim ugovorom kojim se vladaru prenesu sve ovlasti kako bi ljude štitio od njih samih. Odbacujući klasično učenje da je čovjekova najviša težnja potraga za srećom, Hobbes kaže: »Kao opću težnju čovječanstva na prvo mjesto stavljam vječnu i neprestanu želju za jednom moći nakon druge, koja prestaje samo u smrti. « ${ }^{21}$ Pored toga da čovjek u bližnjem prepoznaje svoga neprijatelja pa onda slijedi da se mora odreći svojih "prirodnih " prava i prenijeti ih vladaru da mu osigura sigurnost, Hobbes dodaje da

»želja za lagodom i osjetilnim užicima čini čovjeka poslušnim prema nekoj općoj moći, jer takvom željom čovjek stvarno napušta zaštitu kojoj se može nadati od svoga vlastitog napora i rada«. ${ }^{22}$

Dakle, dva su ključna razloga za građansku poslušnost vladaru: ljubav prema lagodi i užicima i strah od nasilne smrti.

Važno je naglasiti da Hobbesova teorija ne podnosi dva gospodara ili autoriteta, nego to može biti samo jedan, i to onaj zemaljski vladar. On svoju poziciju izražava eksplicitnije od Machiavellija koji je donekle »skrivao« svoje prave namjere od naroda. Budući da je Hobbesova teorija relativistička, ne postoji moralna norma prema kojoj bi se moglo suditi vladarove odluke. Ono što nam Hobbes predlaže jest apsolutna vladavina, ali bez Boga, utemeljena isključivo na materijalističkim i relativističkim temeljima. Sve mora biti pod kontrolom vladara, uključujući i Crkvu, jer ne smije dopustiti da postoji suparnički autoritet koji bi ga mogao ugroziti, što znači da ne može biti distinkcija između svjetovne (političke) i duhovne sfere. Iako ga njegov materijalizam vodi do zaključka da »neznanje prirodnih uzroka čini ljude lakovjernim tako da često vjeruju u nemoguće stvari ${ }^{23}{ }^{23}$ svjestan je da je vjera snaga koja pokreće ljude, tako da velik napor ulaže kako bi opravdao legitimitet vrhovnog vladara da odlučuje o vjerskim pitanjima. U trećem dijelu Levijatana pod naslovom »O kršćanskoj državi« Hobbes objašnjava da vrhovni vladar ili »Božji namjesnik« mora imati konačnu riječ kad je u pitanju i vjera jer se to ne može prepustiti privatnoj prosudbi. Ovdje izričito spominje čak i Euharistiju o kojoj kaže sljedeće:

»Moramo se obratiti Božjem namjesniku kojemu u svim dvojbenim slučajevima podređujemo svoje privatne prosudbe. Na primjer, ako netko, nakon što izgovori određene riječi nad komadićem kruha, tvrdi da ga Bog u tom času nije učinio kruhom, već Bogom, čovjekom ili oboma, a to svejedno i dalje izgleda

\footnotetext{
${ }^{20}$ Usp. Strauss, Cropsey (ur.), Povijest političke filozofije..., 281.

${ }^{21}$ Hobbes, Levijatan..., 74.

${ }^{22}$ Isto, 75.

${ }^{23}$ Isto, 78.
} 
slično kruhu kao što je uvijek izgledalo, ne postoji ni jedan razlog da itko to smatra učinjenim i, dosljedno tome, da ga se boji dok ne pita Boga po njegovu zastupniku ili namjesniku, je li to učinjeno ili nije. ${ }^{24}$

Poznato je da se Hobbes obračunavao s tadašnjim autoritetima Katoličke crkve, posebno s kardinalom Robertom Bellarmineom. ${ }^{25}$ Božji namjesnik za Hobbesa može biti samo vrhovni vladar, s ne poglavar Katoličke crkve, kao što je tvrdio Bellarmine. Hobbes dovodi u pitanje postojanja Crkve kao institucije kad kaže da »skupština koja nema dopuštenje vrhovnoga građanskog vladara nije dopuštena ni u jednoj državi«, te kasnije dodaje da

»ne postoji u ovome životu ni jedna druga vladavina ni države ni religije, osim svjetovne, niti je bilo kojem podaniku dopušteno naučavanje bilo koje doktrine čije naučavanje zabrani vladar koji je i nad državom i nad vjerom «. ${ }^{26}$

Hobbes osporava i Crkvi pravo da tumači Sveto pismo jer bi to opet značilo da bi, pored vrhovnoga vladara mogao postojati još jedan mjerodavan autoritet, tako da konačna riječ o Svetom pismu također pripada svjetovnom vladaru. ${ }^{27}$ $\mathrm{U}$ četvrtom dijelu Levijatana pod naslovom »O kraljevstvu tame« Hobbes ide korak dalje u svom obračunu s Crkvom i kaže sljedeće:

»Najveća i glavna zloupotreba Svetog pisma, iz kojeg sve ostalo slijedi ili joj služi, jest njegovo izvrtanje radi dokazivanja da je kraljevstvo Božje, koje se često spominje u Svetom pismu, sadašnja Crkva ili ukupnost sada živućih kršćana ili pak mrtvih koji će opet ustati na Sudnji dan. ${ }^{28}$

Vidimo da Hobbes nije ponudio samo novu političku filozofiju, nego i teologiju. Prema Laurenceu Bernsu:

»Hobbes je htio da čitatelji njegove teologije izvuku zaključak da u biti doista nema bitne razlike između Božje riječi objavljene u Pismu i Hobbesove riječi izložene u njegovoj političkoj filozofiji.« ${ }^{29}$

U odnosu na Machiavellija Hobbes ide dalje u stvaranju sekularne države potpuno oslobođene od vanjskog utjecaja, jer Hobbesova država nije samo neovisna tvorevina nego treba imati vlast i nad Crkvom. Svjetovni vladar je taj koji ima konačnu riječ i u vjerskim pitanjima, tako da ne postoji više dualizam

\footnotetext{
${ }^{24}$ Isto, 292.

${ }^{25}$ Isusovac Bellarmine, jedna od vodećih osoba Katoličke crkve 17. stoljeća, bio je i među najznačajnijim sudionicima protureformacije, koja je uslijedila nakon Tridentskog sabora. Zbog svojih vrlo vrijednih teoloških djela proglašen je crkvenim naučiteljem.

${ }^{26}$ Hobbes, Levijatan..., 306-307.

${ }^{27}$ Hobbes u Levijatanu posvećuje jedno cijelo poglavlje (XXXIII) pitanjima Svetoga pisma i njegova tumačenja. Engleski povjesničar Richard Tuck tvrdi da je Hobbes u ranijoj fazi svoga djelovanja ipak priznao crkvenoj vlasti pravo na tumačenje Svetoga pisma, ali da je poslije u Levijatanu odustao od tog stava (vidi Richard TUCK, Introduction to the Leviathan, Cambridge, 1991).

${ }^{28}$ Hobbes, Levijatan..., 396-97.

${ }^{29}$ Strauss, Cropsey (ur.), Povijest političke filozofije..., 296.
} 
između duhovnog i zemaljskog svijeta. Ono što je stvarno revolucionarno, međutim, jest ono što proizlazi iz Hobbesove materijalističke pretpostavke. Za razliku od dotadašnjih teorija o porijeklu vlasti koje su tvrdile da vladar crpi svoju vlast od Boga, Hobbes pažljivo gradi nov temelj za politički poredak ne polazeći od Boga prema kralju, nego odozdo na temelju mehanicističke slike čovjeka. U njegovoj stvarnosti postoji samo materija; nema besmrtne duše, nema dobra i zla, pravednosti i nepravednosti, nego samo tjelesni objekti u pokretu i pojedine volje koje su u potrazi za užitkom i žele izbjeći nasilnu smrt.

\section{Klasični liberalizam}

Vidimo da Hobbesov liberalizam nije previše liberalan jer daje gotovo neograničenu moć vladaru. S druge strane, imamo drugu vrstu liberalizma, nazovimo ga »klasičnim liberalizmom « koji se razvio tijekom 17. i 18. stoljeća, a stavlja naglasak na slobodu pojedinca i njegova prirodna prava. Klasični liberalizam, primjerice, u početku nije imao protureligiozni karakter, nego je uključio i vjersku toleranciju kao sastavni dio doktrine. Prva značajna skupina koja se zalagala za vjersku toleranciju je bila francuska politička stranka ( $L e$ Parti des Politiques), sastavljena od umjerenih katolika koji su pokušali pronaći modus vivendi između katolika i protestanata tijekom vjerskog rata u toj zemlji. ${ }^{30}$ Kasnije, engleski filozof John Locke, uzimajući u obzir da je religija postala uzrok podjela i sukoba, a ne jedinstva, obrazložio je načela vjerske tolerancije u svom pismu iz 1689. godine. ${ }^{31}$ Glavna Lockeova pretpostavka jest da je pobožnost sastavni dio ljudske naravi te nešto potrebno i poželjno za liberalno društvo, tako da država ne smije ograničavati vjerske slobode. Međutim, njegova filozofija "prirodnih prava« nije bitno drugačija od Hobbesove, jer obje tvrde da politička zajednica nastaje umjetnim putem, a glavni motiv svakog pojedinca u tom procesu jest ostvariti svoj interes. Kod Lockea, glavni interes je zaštititi svoju imovinu. Ovaj proces stvaranja vlade uključuje dva ugovora: prvi je između slobodnih građana da prenesu vlast izabranom vladaru, a drugi je između građana i vlade koja dobiva strogo definirane funkcije i ovlasti. ${ }^{32}$

Iako dijeli s Hobbesom sličnu viziju prirodnog stanja i slaže se da je najmoćnija sila u čovjeku poriv za samoodržanjem, Locke nas ipak želi osloboditi svakog oblika apsolutne arbitrarne vlasti, pa zato inzistira na načelu odvajanja vlasti. Locke kaže da su »u dobro uređenim državama« glavne vlasti odijeljene

\footnotetext{
${ }^{30}$ Usp. Thomas NEILL, The Rise and Decline of Liberalism, Milwaukee, 1953, 41-42.

${ }^{31}$ Usp. John LOCKE, A Letter Concerning Toleration (Pismo o toleranciji), London, 1689. Važno je spomenuti da je ovo djelo objavljeno anonimno.

${ }^{32}$ Ovo poimanje političke vlasti podrazumijeva da je svrgavanje vlasti opravdano, ako ona prekorači svoje ovlasti ili ih zloupotrijebi na štetu naroda. Stoga je Lockeova filozofija služila kao osnova za američku pobunu protiv britanske vlasti.
} 
»jer može biti odveć velika kušnja za ljudsku slabost, spremnu dočepati se vlasti, ako bi isti ljudi koji imaju vlast donošenja zakona imali u svojim rukama vlast da ih izvršavaju «. ${ }^{33}$

Svjestan je da prijetnja čovjekovoj slobodi ne dolazi samo od drugog čovjeka, nego može doći od same vlasti kad prekorači ovlasti. U ovom smislu bismo mogli reći da je Lockeova filozofija liberalnija u odnosu na Hobbesovu, jer ne inzistira na tomu da politička moć bude nepodijeljena. Ne govori o jednom vrhovnom vladaru koji mora imati konačan sud o svim pitanjima. Međutim, Lockeova teza da je glavna svrha vlade štititi život i imovinu, ipak ga svrstava u skupinu liberala koji definiraju državu kao strogo sekularnu tvorevinu koja se brine isključivo o materijalnim stvarima. ${ }^{34}$

Što se tiče religije, Locke se zalagao za oblik kršćanstva koji nije stavljao naglasak na vjerske dogme, nego je trebao biti tolerantan i »razuman «. ${ }^{35}$ Bio je uvjeren da vjera ima svoje mjesto u društvu te da je potrebna za usađivanje moralnog osjećaja u narodu. Pokušao je minimalizirati značaj doktrine i reducirati kršćanstvo na moralni sustav koji ipak obvezuje mase na odgovorno ponašanje. Prema ovom shvaćanju, Isus Krist je bio veliki moralni propovjednik, ali nije radio čudesa niti je bio božanska osoba. Ovo vjerovanje je blisko liberalnom protestantizmu ili deizmu, u što je i Locke osobno vjerovao. Njegova je filozofija pretpostavljala da se sva religijska uvjerenja moraju tolerirati, sve dok vjernik poštuje zakone države. ${ }^{36}$ Ova liberalna doktrina izjednačila je slobodu s odsutnosti vanjske prisile, tako da više nije shvaćena kao pozitivna kvaliteta koja daje čovjeku mogućnost da ispuni svoju svrhu na zemlji, nego više kao nešto negativno što se dobiva reduciranjem vanjske prisile. U kršćanskoj tradiciji ne postoji nužno sukob između slobode i autoriteta, dok su u modernom liberalnom shvaćanju one suprotstavljene. Dakle, u interesu je pojedinca da se svaki oblik autoriteta, bilo to političkog, crkvenog ili društvenog, što više smanji kako bi se apsolutna sloboda mogla realizirati. ${ }^{37}$ Za religiju to znači da se ona mora svesti na privatnu sferu pojedinca, jer politička sfera mora ostati sekularna ili neutralna u odnosu na vjerska pitanja. Ovakav liberalizam završava s pojedincima koji

\footnotetext{
${ }^{33}$ John LOCKE, The Second Treatise on Government, New York, 1952, br. 143, prema: Strauss, Cropsey (ur.), Povijest političke filozofije..., 355.

${ }^{34}$ Locke u Drugoj raspravi o vladi (The Second Treatise on Government) iznosi stav da vlada i religija imaju različite ciljeve, a vlada se treba posvetiti isključivo zemaljskim stvarima.

${ }^{35}$ Objavio je 1695. god. djelo pod nazivom The Reasonableness of Christianity (Razumnost kršćanstva). Također je objavio iscrpne komentare o Svetom pismu.

${ }^{36}$ Važno je napomenuti da Lockeova tolerancija nije vrijedila za katolike koje je smatrao čimbenikom nestabilnosti u engleskom društvu. Uglavnom se odnosila na protestantske zajednice koje nisu priznavale Anglikansku crkvu.

${ }^{37}$ Usp. Guido RUGGIERO, The History of European Liberalism, Boston, 1959, 51. Ruggiero ističe kako liberalizam uključuje i naivnu sliku o čovjeku kao biću koje je »svoj vlastiti kritičar, sudac, zagovornik, upravitelj i vladar«. Može se, dakle, oslanjati isključivo na vlastiti autoritet i uživa potpunu autonomiju.
} 
imaju pravo na vjersku slobodu, ali se religija posve subjektivizira do te mjere da na kraju imamo samo izolirane građane koji se moraju pokoriti državi.

Iako su mnogi osnivači SAD-a bili kršćanski vjernici u vrijeme osamostaljenja od britanske vlasti, njihovo poimanje slobode bilo je formirano u skladu s pretpostavkama ovog oblika liberalizma. Za njih je glavna svrha vlasti bila osigurati neotuđiva prava, prije svega, na »život, slobodu i traženje sreće.$^{38} \mathrm{Kad}$ čitamo, primjerice, prijepisku između vodećih ljudi koji su pisali Deklaraciju o neovisnosti, kao i američki ustav, možemo primijetiti da su bili vrlo svjesni da je vjerska sloboda jedna od prvih i temeljnih prava svakog pojedinca. ${ }^{39} \mathrm{Kad}$ se govorilo o načelu odvojenosti Crkve od države, američki su državnici mislili, prije svega, na to da se država ne miješa $u$ život vjerskih organizacija i njenih članova. ${ }^{40}$ Međutim, htjeli su također isključiti mogućnost da neka crkva postane toliko snažna da bi mogla ugroziti autoritet političke vlasti, tako da Madison, primjerice, kaže kako nije primarno pitanje koja je kršćanska denominacija ona prava, nego kako spriječiti da jedna »frakcija « kršćanstva dobije prevlast. ${ }^{41}$ Vjerska sloboda je bila zajamčena, ali s pretpostavkom da nijedna crkva nikad neće moći biti prijetnja državnoj vlasti.

Prvi članak ustavnih odredaba koje jamče temeljna prava (Bill of Rights) počinje riječima koje zabranjuje zakonodavcu (Congress) donošenje zakona o uspostavljanju državne religije, kao ni zakona koji zabranjuje slobodno ispovijedanje vjere. Ovo ukazuje da je autorima američkog ustava vjerska sloboda bila na samom vrhu temeljnih prava, a također i njihovo uvjerenje da je odvajanje Crkve od države poželjno. Treba ovdje spomenuti da se ustavna odredba odnosila samo na saveznog zakonodavca, ne na pojedine savezne države. A neke od njih su imale etablirane crkve sve do 1833 . godine. ${ }^{42}$ Dakle, u vrijeme osnivanja SAD-a praksa da se nekim crkvama daje povlašteni status bila je uobičajena i nesporna. Savezne države su imale veliku autonomiju i dugo su bile glavni nositelji građanskog identiteta, tako da su one davale i oduzimale državljanstvo sve do građanskog rata sredinom 19. stoljeća, kad je izmjenom ustava državljanstvo postalo pitanje savezne vlade. Dugo vremena su ustavi pojedinih saveznih država bili glavna referentna točka u tumačenju vjerske slobode, a ne

\footnotetext{
${ }^{38}$ Deklaracija o neovisnosti iz 1776. godine u uvodnom dijelu proglašava neotuđiva prirodna prava čovjeka na život, slobodu i traženje sreće. Izričito kaže da je Bog izvor neotuđiva prava.

${ }^{39}$ James Madison, primjerice, žestoko je osudio progon baptista u saveznoj državi Virginiji, gdje je Anglikanska crkva bila etablirana kao službena vjerska institucija. Thomas Jefferson se također zalagao da nijedna religija nema povlašteni status u odnosu na druge.

${ }^{40}$ Madison je 1785. god. objavio poznato djelo Memorial and Remonstrance against Religious Assessments u kojemu je branio načelo odvojenosti crkve od države. Djelo počinje apelom da religija pripada »uvjerenju i savjesti svakog čovjeka; i pravo je svakog čovjeka je prakticirati kako mu ona to nalaže«.

${ }^{41}$ Usp. James MADISON, Federalist Paper X, Washington DC, 1998, 112.

${ }^{42}$ Savezne države Connecticut i Massachusetts, primjerice, dopustile su građanima da sami odrede koje će se protestantske zajednice financirati njihovim porezima. Massachusetts je ovu praksu ukinuo tek 1833. godine.
} 
savezni ustav. Ova se praksa radikalno mijenjala tek sredinom 20. stoljeća kad je Vrhovni sud počeo tumačiti značenje 14. članka ustava koji određuje odnos između svih država i savezne vlade. ${ }^{43}$ Podjelom vlasti na tri grane - zakonodavnu, izvršnu i pravosudnu - uspjelo se spriječiti uzurpiranje političkom moći i njezino centraliziranje na jednom mjestu, što je pretpostavka za slobodno društvo. Međutim, ta se osjetljiva ravnoteža počela urušavati u novije vrijeme, pogotovo zbog kontroverznih presuda Vrhovnog suda. ${ }^{44}$

\section{Sekularni liberalizam kao novi totalitarizam}

Kad je riječ o moralu i vjeri vidjeli smo da liberali ostavljaju to pitanje svakom pojedincu da sam odredi što je dobro i odbacuju tvrdnju da postoji moralni ili naravni zakon koji obvezuje sve ljude, bez obzira na njihov svjetonazor. Međutim, nameće se pitanje kako postići konsenzus u društvu koje je sastavljeno od ljudi koji imaju vrlo različita poimanja o dobru? Iskustvo pokazuje da ljude, pojedinačno ili skupno, privlače različita dobra, poput bogatstva, časti, slobode ili kreposti. Je li uopće moguće sačuvati slobodno društvo bez neke obuhvatne moralne doktrine koja bi bila obvezna za sve? U novije vrijeme liberalizam, nazovimo ga »sekularnim liberalizmom«, ima tendenciju reducirati društvenu stvarnost na odnos između države i pojedinca, što podrazumijeva slabljenje drugih oblika pripadnosti kao što je obitelj, lokalne zajednice ili crkve. Američki sociolog Robert Nisbet ovako opisuje ovu tendenciju:

»Povijest zapadnih država obilježava postupno apsorbiranje moći i odgovornosti, koje su prije pripadale drugim zajednicama, te sve veću neposrednost odnosa između suverene vlasti države i pojedinog građanina.« ${ }^{45}$

Budući da demokratsko društvo čine građani koji su jednako slobodni, ciljevi ostaju strogo privatna stvar pojedinca, tako da pitanje o dobru nestaje iz javnog prostora. Međutim, odmah se pojavljuje problem da nije moguće jednako tretirati sve ciljeve jer neizbježno dolazi do sukoba između njih. Ukoliko želimo raspravljati o njima na razuman način, moramo ih smjestiti u veći okvir koji će nam reći što su zapravo ti ciljevi, u kakvom su međusobnom odnosu i koliko vrijede. S obzirom da sekularni liberalizam pokušava zauzeti neutralan stav prema svim životnim opredjeljenjima, onda ističe toleranciju kao glavnu

\footnotetext{
${ }^{43}$ Članak 14., koji je donesen 1868. godine, jamči sva prava iz saveznog ustava svim građanima bez obzira na mjesto prebivališta. Ovo je značajno jer su do tada pojedine države, primjerice, mogle čak dopustiti čak i ropstvo na svom teritoriju.

${ }^{44}$ Prva kontroverzna presuda glede vjerske slobode je bila u slučaju Everson protiv Board of Education iz 1947. godine. Iz presude proizlazi da odvajanje države od Crkve zapravo znači da javni prostor mora biti lišen svakog vjerskog sadržaja. Jedna od posljedica bila je da su postali sporni tradicionalni izrazi vjerovanja kao javna molitva u školama ili prikazivanje Deset Božjih zapovijedi.

${ }^{45}$ Robert NISBET, Quest for Community, San Francisco, 1990, 94.
} 
moralnu vrlinu. Na kraju, postavlja se pitanje je li sekularni liberalizam zaista neutralan ili je možda neka vrsta građanske ili državne religije sa svojim definiranim »dogmama« koje su obvezne za sve?

Neki govore o »sekularnoj revoluciji« koja je prethodila nedavnim presudama Vrhovnog suda, tako da američke institucije na službeni način samo odražavaju ono što je već prihvaćeno u široj kulturi. ${ }^{46}$ Teza o organiziranom djelovanju s ciljem da se smanji kršćanski utjecaj u javnom prostoru upućuje na to da ovakav razvoj događaja nije bio neizbježan. Naprotiv, riječ je o nametanju vrlo konkretne vizije čovjeka i naravi društva, koristeći službene institucije, prije svega sudova. Američki kritičar liberalizma Russell Kirk ovako opisuje ovu sekularnu filozofiju:

"Sumnja u tradiciju, autoritet, stvari odavno utemeljene; duboko nagrizajuća sumnja u dugotrajno vjerovanje u stalnu ljudsku prirodu; posebice sumnja u čovjekovu moć moralnog izbora i čovjekovu moralnu odgovornost za vlastite postupke. «7

Ova je filozofija politička, a ne metafizička, tako da nema mjesta, primjerice, za doktrinu naravnog zakona koja nudi koherentnu filozofsku podlogu za uređivanje slobodnog i pravednog društva bez pozivanja na religijska načela. U praksi to znači da se kontroverzne teme poput pobačaja, eutanazije i homoseksualnog »braka« obično percipiraju kao »katoličke« ili »vjerske« teme, iako to zapravo nisu. Može se, dakako, argumentirano zauzimati protiv legalizacije ovih pojava i bez pozivanja na Sveto pismo ili objavljenu istinu. Na primjer, načelo da je ubijanje nevine osobe uvijek moralno nedopustivo jest načelo koje nam praktični razum nameće i time je prihvatljivo svima.

Činjenica jest da je nedavna presuda u slučaju Obergefell kojom se redefinira brak izazvala velike i žestoke rasprave u javnosti. Ono što zapravo sekularni liberalizam provodi nije neutralnost $\mathrm{u}$ javnom prostoru, nego uspostavljanje novog moralnog poretka u kojemu će neke skupine moći ostvariti svoje interese. Ovaj novi poredak je utemeljen na moralnom relativizmu, na "pravima« umjesto na naravnom zakonu i na materijalističkom hedonizmu - sve što je prisutno već u Hobbesovoj filozofiji. Moglo bi se reći da su to glavne odrednice nove sekularne religije koja ne daje građanima pravo da je odbace, nego ih putem zakona obvezuje i zahtijeva poslušnost. U ovim okolnostima vjerska sloboda i sloboda savjesti gube svaki smisao i ostaju samo mrtvo slovo na papiru. Papa Ivan Pavao II. upozoravao je na ovu opasnost u enciklici Centesimus annus u kojoj utvrđuje da Crkva »ne može podržati formiranje uskih vodećih

\footnotetext{
${ }^{46}$ Primjerice, američki sociolog Christian Smith govori o postupnoj sekularizaciji američkog javnog života kao posljedici organiziranog djelovanja sekularnih aktivista. Ovo djelovanje počelo je na sveučilištima, ali s vremenom se proširilo u medije i političke strukture (vidi Christian SMITH, The Secular Revolution. Power, Interests, and Conflict in the Secularization of American Public Life, Berkeley, 2003).

${ }^{47}$ Russell KIRK, Politika razboritosti, Zagreb, 2015, 125.
} 
skupina koje radi zasebnih interesa ili radi ideoloških ciljeva uzurpiraju državnu vlast « ${ }^{48}$ Isto tako je predvidio mogućnost da se »ideje i uvjerenja mogu lako instrumentalizirati u svrhe moći ako ne postoji nikakva posljednja istina koja usmjerava političku akciju «. ${ }^{49} \mathrm{Na}$ kraju konstatira da se »demokracija bez načela lako pretvara u otvoreni ili skriveni totalitarizam «.50

\section{Zaključak}

Liberalizam nije jednoznačan pojam, a kao filozofsko mišljenje dobivalo je različite oblike od svojega nastanka u 16. stoljeću. Jedno vrijeme činilo se da može služiti kao podloga za uređivanje slobodnog i demokratskog društva. Međutim, ako promatramo suvremeni sekularni liberalizam kao oblik državne religije, onda vidimo da zapravo potkopava i niječe glavna moralna načela kršćanske vjere. Ona dopušta postojanje liberalne verzije kršćanstva koja prihvaća premise sekularnog liberalizma, ali nema mjesta za obuhvatnu moralnu viziju koju nudi, primjerice, Katolička crkva. Sekularni liberalizam uvelike se definira svojim protivljenjem moralnom nauku koji je kršćanstvo usadilo u zapadnu kulturu kroz stoljeća. Nedavni sudski slučajevi u SAD-u ukazuju na to da će biti vrlo teško pronaći novi modus vivendi koji će omogućiti slobodno ispovijedanje vjere. Kao što ljudsko iskustvo jasno pokazuje, dvije religije ili dvije sasvim različite sveobuhvatne moralne doktrine ne mogu istovremeno obvezivati ljude, nego po naravi stvari jedna mora preuzeti vodeću ulogu u društvu na štetu druge.

\footnotetext{
${ }^{48}$ IVAN PAVAO II., Centesimus annus, Rim, 1991, br. 46.

${ }^{49}$ Isto.

${ }^{50}$ Isto.
} 
Stephen Nikola Bartulica*

Liberalism and Religion

Summary

The author explores the relationship between the political philosophy of liberalism and religion in the secular state. Machiavelli elaborated his theory of the secular State before the Protestant Reformation, claiming that it must be independent of all external influence, including that of the Church. Hobbes argues for the State to be the sole lawmaker and must have the final word in matters of religion as well. Later liberalism tried to adapt and find a way to secure religious liberty and succeeded for a time, for example in the United States. However, recent developments have revealed a disturbing trend involving the creation of new secular "dogmas" which are incompatible with Christian teaching.

Key words: Liberalism, religion, Machiavelli, Hobbes, Locke, freedom, totalitarianism.

(na engl. prev. Stephen Nikola Bartulica)

\footnotetext{
* Stephen Nikola Bartulica, post-doctoral fellow, Catholic University of Croatia; Address: Ilica 242, HR-10000 Zagreb, Croatia; E-Mail: stjepo.bartulica@unicath.hr.
} 